\title{
Teucrium micranthum (Labiatae), a new species from Queensland, Australia
}

\author{
Barry J. Conn
}

\begin{abstract}
Conn, Barry J. (Royal Botanic Gardens, Mrs Macquaries Road, Sydney NSW 2000, Australia) 2002. Teucrium micranthum (Labiatae), a new species from Queensland, Australia. Telopea 9(4): 803-807. Teucrium micranthum from Queensland, an erect subshrub, moderately to densely covered in multi-branched hairs and with \pm persistent ovate, petiolate prophylls, is described as new. A key is provided to the three species of Teucrium in Queensland that have non-podiate flowers.
\end{abstract}

\section{Introduction}

In 1988, D. Fell first collected a fruiting specimen of an unknown labiate from Broken River in central Queensland. Unfortunately, it was not possible to confirm the generic placement of this collection, even though it appeared to be an undescribed species of Teucrium. Subsequent additional fruiting collections by other field workers (for details, refer 'Other specimens examined' below) have been made since that time and the taxon as been informally referred to as 'Teucrium sp. (Ka Ka Mundi NP A.R.Bean 2170)' (Forster 2002). The author collected the first flowering specimens of this taxon from the Carnarvon National Park of Queensland. These collections confirmed that the taxon was an undescribed species of this genus. With the description of this new species, there are now eight named species of Teucrium occurring in Queensland and an additional species to be formally described, namely, 'Teucrium sp. (Ormeau G. Leiper AQ476858)'. The latter species is a small shrub to about $0.5 \mathrm{~m}$ high, with ovate to slightly oblong lobed leaves to about $10 \mathrm{~mm}$ long and shortly podiate flowers.

Terminology follows Conn (1984), except for modifications to inflorescence terminology and the definition of podium (Conn 1995).

Teucrium micranthum B.J. Conn, sp. nov.

T. argutum R.Br. indumento ramosissimo prophyllis petiolatis ovatis differt.

Type: Queensland: Leichhardt District: Carnarvon National Park (Ka Ka Mundi Section), Tom's Tank, $3.4 \mathrm{~km}$ E of Park Boundary $\left(24^{\circ} 47^{\prime} \mathrm{S}, 147^{\circ} 25^{\prime} \mathrm{E}\right)$, B.J. Conn 4146, E.A. Brown E N.A. Leist, 25 May 1999 (holo NSW 428108; iso BRI).

[Teucrium sp. (Ka Ka Mundi NP A.R.Bean 2170) (Forster 2002)]

Erect subshrub 0.1-0.3(-1) m high, producing erect branches from a thick woody stem and rootstock. Branches \pm quadrangular, slightly ridged on angles to many-ridged and channelled (especially on older branches), moderately to densely hairy; hairs multibranched (shortly stalked), \pm patent, $0.1-0.2 \mathrm{~mm}$ long, white; moderately to densely glandular (especially in channels); glands hemispherical, sessile. Leaves aromatic, shortly petiolate; petiole to $1 \mathrm{~mm}$ long; lamina ovate to almost elliptic, light to midgreen, 4-7 mm long, 3-7 mm wide, with length 1-1.7 times width, distance from base of maximum width 0.3-0.5 times total lamina length; abaxial and adaxial surfaces moderately to densely glandular (glands as for branches), moderately to densely hairy 
(hairs as for branches), margin entire, \pm strongly recurved; apex obtuse to almost rounded, appearing narrower because margin often strongly recurved; venation mostly indistinct due to indumentum cover, midvein slightly raised on abaxial surface. Inflorescence a frondose racemiform conflorescence, 4-20-flowered, appearing as single flowers in axils; uniflorescence monadic. Podium minute, to $0.5 \mathrm{~mm}$ long, densely hairy (as for branches). Prophylls \pm persistent, inserted distally near base of calyx (propodium c. $0.4 \mathrm{~mm}$ long; anthopodium c. $0.1 \mathrm{~mm}$ long, with propodium c. 4 times length of anthopodium), opposite, shortly petiolate (petiole c. $0.3 \mathrm{~mm}$ long); lamina ovate, 1-1.5 mm long, 0.6-0.8 mm wide, flattened, densely hairy (as for branches). Calyx green, campanulate; outer surface densely hairy (as for branches), midveins not prominent; tube c. $1 \mathrm{~mm}$ long, inner surface glabrous; lobes equal, triangular, c. $1 \mathrm{~mm}$ long, c. $0.8 \mathrm{~mm}$ wide at base, with length c. 1.3 times width, inner surface densely hairy (as for branches), apex subacute and minutely apiculate. Corolla $2.5-3 \mathrm{~mm}$ long, white; outer surface of lobes sparsely hairy (hairs as for branches, except some simple hairs also present), moderately glandular; inner surface moderately hairy in tube, hairs simple, spreading, c. $0.1 \mathrm{~mm}$ long; tube $1.3-1.5 \mathrm{~mm}$ long; abaxial median lobe ovate to slightly elliptic, c. $1.5 \mathrm{~mm}$ long, c. $1.2 \mathrm{~mm}$ wide, with length c. 1.3 times width, apex rounded; lateral lobes and adaxial median lobe-pair \pm oblong, $1-1.3 \mathrm{~mm}$ long, 1.4-1.8 mm long, with length c. 0.7 times width (each lobe $0.7-0.9 \mathrm{~mm}$ wide, with length $1.4-1.6$ times width), apex obtuse. Stamens inserted c. $0.4 \mathrm{~mm}$ above base of corolla; filaments to $1-1.5 \mathrm{~mm}$ long, sparsely hairy near base (as for inner surface of corolla tube); anthers $0.4-0.6 \mathrm{~mm}$ long, $0.5-0.7 \mathrm{~mm}$ wide. Pistil 3-3.5 mm long, strongly curved (towards abaxial plane); ovary cylindrical obovoid, $0.5-0.8 \mathrm{~mm}$ long, diameter $0.7-0.8 \mathrm{~mm}$, lobes c. $0.1 \mathrm{~mm}$ long, glabrous, white distally; style $2-2.5 \mathrm{~mm}$ long; stigma lobes $0.8-1 \mathrm{~mm}$ long, soon becoming \pm strongly deflexed. Fruiting propodium extended to c. $1.5 \mathrm{~mm}$ long. Fruiting calyx enlarged, yellow-green, maturing to dark brown, 3-3.5 mm long, densely glandular distally. Mature mericarps c. $2 \mathrm{~mm}$ long, with radial surfaces and basal half of tangential surface light brown and smooth, distal half of tangential surface and apex thickened and whitish to very pale fawn-coloured. (Fig. 1).

Other specimen examined: Queensland: North Kennedy District: Broken River, $1 \mathrm{~km}$ SW of Jack Hills Gorge, Wandovale Holding (19³0'S, 14445'E), D.G. Fell 850, 13 Apr 1988 (NSW); Broken River (19²5'57"S, 144²4'25"E), R.J. Fensham 1036, 16 Jun 1993 (BRI). Leichhardt District: Duaringa

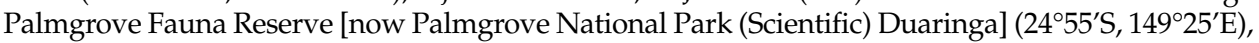
S. Barry PG25, 6 Jun 1989 (BRI); Carnarvon National Park (Ka Ka Mundi Section), north-eastern

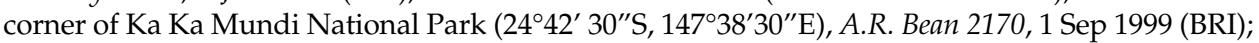

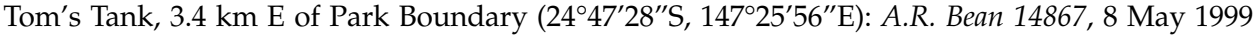
(BRI); B.J. Conn 4144, 4145, 4147, E.A. Brown E N.A. Leist, 25 May 1999, (BRI, NSW); Mantuan Downs, fenceline south of Police Creek, $10 \mathrm{~km}$ WNW of Mantuan Downs Homestead (24 23' $25^{\prime \prime} \mathrm{S}$, $\left.147^{\circ} 08^{\prime} 58^{\prime \prime} \mathrm{E}\right)$, D. Butler s.n., 26 Jun 1999 (BRI AQ490658).

Distribution: this species is known from the North Kennedy and Leichhardt Botanical Districts, Queensland. (Fig. 2).

Habitat: this species occurs in tall woodland, low Brigalow (Acacia harpophylla) open forest with tall Brigalow and Eucalyptus cambageana emergents, scrub of Brigalow and Poplar Box (Eucalyptus populnea), or open woodland of Eucalyptus melanophloia, E. populnea, E. orgadophila and Acacia excelsa, with \pm open shrubby understorey. It grows in red cracking clay to brown loam soils. However, in the North Kennedy District it was collected from vinethicket on limestone karst-derived soils (Fensham 1036).

Etymology: the specific epithet (viz. micranthum) refers to the small corolla of this species that just extends beyond the calyx. 


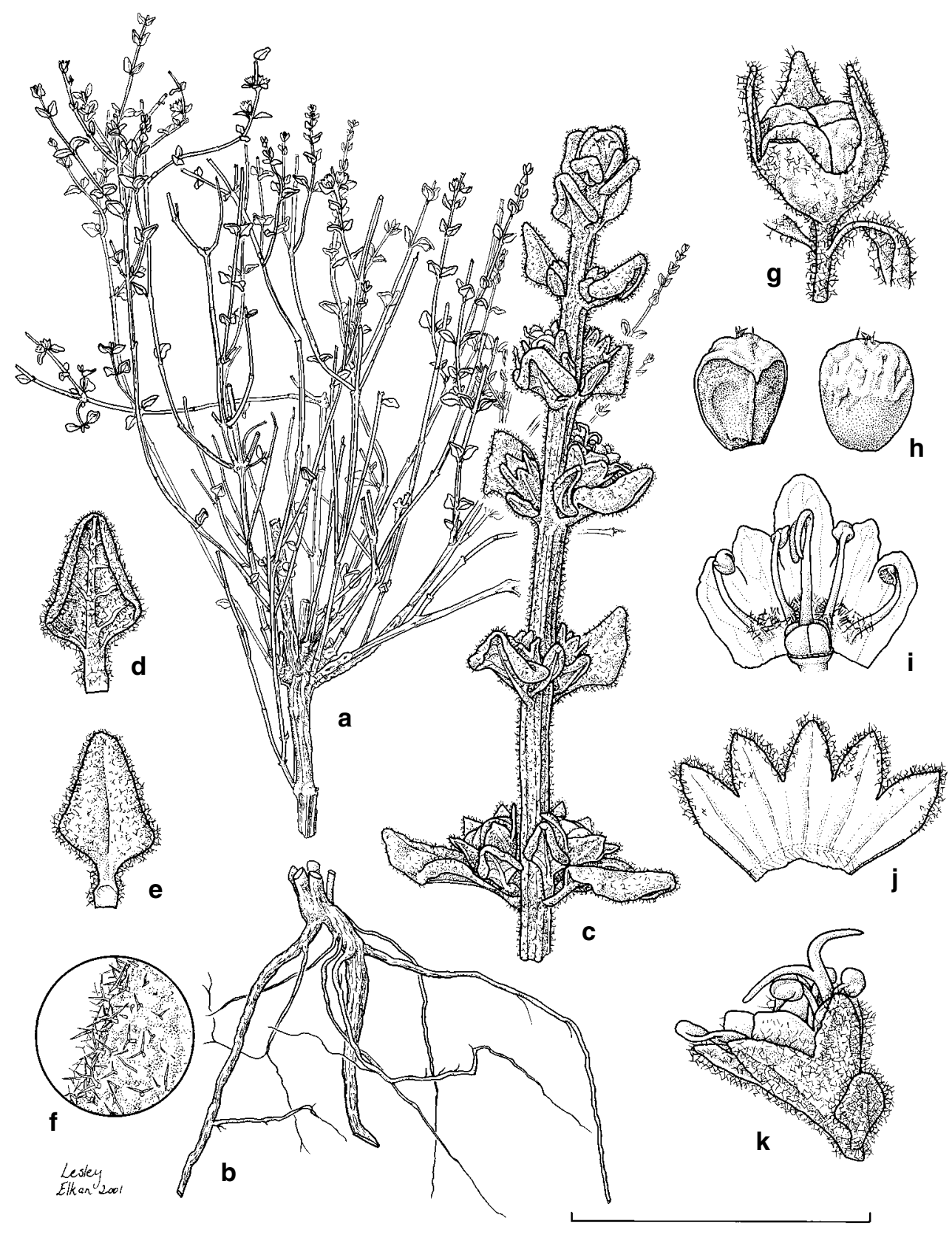

Fig. 1. Teucrium micranthum B.J. Conn a, habit (Conn 4146); b, root system (Fell 850); c-k (Conn 4146): c, branchlet, showing flowers and calyces in fruit; $\mathbf{d}$, leaf, showing densely hairy abaxial surface and \pm prominent veins; e, leaf, showing moderately to densely hairy adaxial surface; $\mathbf{f}$, detail of branched hairs of adaxial leaf surface; $\mathbf{g}$, fruit and fruiting calyx, showing prophylls; $\mathbf{h}$, mericarps, left - showing radial and distal thickened surfaces, right - showing tangential and distal thickened surfaces; $\mathbf{i}$, open corolla, showing hairy inner surface of tube, androecium and gynoecium; j, open calyx; $\mathbf{k}$, flower, lateral view. Scale bar: a \& b $=75 \mathrm{~mm} ; \mathrm{c}=12 \mathrm{~mm}$; $\mathrm{d}$ \& $\mathrm{e}=$ $7.5 \mathrm{~mm} ; \mathrm{f}=2.5 \mathrm{~mm} ; \mathrm{g}-\mathrm{k}=5 \mathrm{~mm}$. 


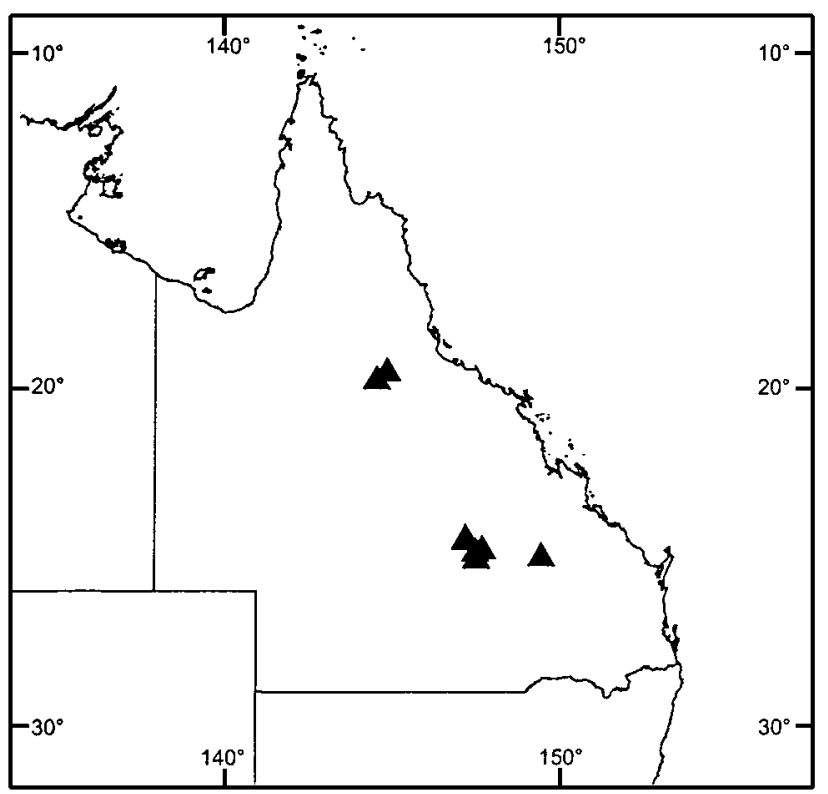

Fig. 2. Distribution map of Teucrium micranthum.

Notes: Teucrium micranthum is a subshrub characterised by a moderate to dense indumentum of multi-branched hairs and by ovate prophylls that are petiolate. The affinities of this species are not known.

Conservation status: this species does not appear to be rare or threatened and has been recorded in several National Parks.

\section{Identification of Teucrium micranthum from other published Queensland species}

The identification key provided by Bailey (1901, p. 1207) to the formally named species of Teucrium occurring in Queensland is here modified to distinguish this new species from the other species that have non-podiate flowers.

... Flowers sessile or nearly so

Leaves mostly 3-6 (or more)-lobed (14-20 mm long)

T. ajugaceum

Leaves \pm entire, toothed or rarely lobed

Branches, leaves and flowers moderately to densely hairy with branched hairs; leaves 4-7 mm long, margin entire; corolla small, just extending beyond the calyx T. micranthum 
Branches, leaves and flowers moderately to densely hairy with unbranched hairs; leaves $15-50 \mathrm{~mm}$ long, margin regularly toothed or crenate; corolla distinctly exceeding calyx

.T. argutum

\section{Acknowledgments}

The botanical illustration of Teucrium micranthum was skillfully drawn by Lesley Elkan (NSW). David Fell (Queensland National Parks \& Wildlife Service) first brought this taxon to my attention. Subsequently, Tony Bean (BRI) provided important additional information that enabled me to locate flowering plants of this species. Peter Bostock (BRI) kindly provided the collection information in an electronic form. Reed Beaman (NSW) prepared figure 2. I thank the Queensland Parks \& Wildlife Service for assisting my research by providing scientific permits and the Service's field staff for generously sharing their local knowledge. I gratefully acknowledge the assistance of staff at the Queensland Herbarium (BRI) for access to their collections and facilities. I thank Elizabeth Brown and Natasha Leist (both NSW) (joint collectors of the type specimen) for their field assistance and companionship.

\section{References}

Bailey, F.M. (1901) Teucrium. Pp. 1206-1208, The Queensland Flora, Part IV (H.J. Diddams \& Co.: Brisbane).

Conn, B.J. (1984) A taxonomic revision of Prostanthera Labill. Section Klanderia (F.v.Muell.) Benth. (Labiatae). Journal of Adelaide Botanic Gardens 6: 207-348.

Conn, B.J. (1995) Description of inflorescence axes in the genus Logania R.Br. (Loganiaceae). Kew Bulletin 50: 777-783.

Forster, P.I. (2002) Lamiaceae. In R.J.F. Henderson (ed.), Names and Distribution of Queensland Plants, Algae and Lichens, pp. 94-98. (Environmental Protection Agency: Brisbane). 
